\title{
The central analgesia induced by antimigraine drugs is independent from Gi proteins: superiority of a fixed combination of indomethacin, prochlorperazine and caffeine, compared to sumatriptan, in an in vivo model
}

\author{
Carla Ghelardini - Nicoletta Galeotti · \\ Elisa Vivoli · Irene Grazioli · Carla Uslenghi
}

Received: 25 May 2009/Accepted: 5 August 2009/Published online: 15 September 2009

(C) The Author(s) 2009. This article is published with open access at Springerlink.com

\begin{abstract}
A hypofunctionality of Gi proteins has been found in migraine patients. The fixed combination of indomethacin, prochlorperazine and caffeine (Indoprocaf) is a drug of well-established use in the acute treatment of migraine and tension-type headache. The aim of this study was to investigate if Indoprocaf was able to exert its central antinociceptive action when Gi proteins activity is abolished by pertussis toxin (PTX), compared to its single active ingredients and to sumatriptan. The mice model of abdominal constriction test induced by an i.p. injection of a $0.6 \%$ solution of acetic acid was used. The study showed that Indoprocaf (a fixed combination of indomethacin $1 \mathrm{mg} / \mathrm{kg}$, prochlorperazine $1 \mathrm{mg} / \mathrm{kg}$ and caffeine $3 \mathrm{mg} / \mathrm{kg}$, s.c.) and sumatriptan $(20 \mathrm{mg} / \mathrm{kg}$, s.c. $)$ exert their central antinociceptive action independently from the Gi proteins. In addition, the antinociceptive efficacy of Indoprocaf in this study was statistically superior to that of sumatriptan. This study also showed that the single active ingredients of Indoprocaf, indomethacin ( $1 \mathrm{mg} / \mathrm{kg}$, s.c. $)$, prochlorperazine $(1 \mathrm{mg} / \mathrm{kg}$, s.c.) and caffeine ( $3 \mathrm{mg} / \mathrm{kg}$, s.c.), were able to exert their central antinociceptive action independently from the Gi proteins. However, Indoprocaf at analgesic doses was able to abolish almost completely the abdominal constrictions, with a statistically higher efficacy compared to the single active ingredients, showing an important synergic effect of Indoprocaf. This synergic effect was evident not only when Gi proteins activity was abolished
\end{abstract}

C. Ghelardini · N. Galeotti · E. Vivoli

Department of Pharmacology, University of Florence,

Viale G. Pieraccini, 6, 50139 Florence, Italy

I. Grazioli · C. Uslenghi $(\bowtie)$

Medical Department, Solvay Pharma S.p.A.,

Via della Libertà, 30, 10095 Grugliasco, Torino, Italy

e-mail: carla.uslenghi@solvay.com by PTX, but also under control condition, when Gi proteins were active. This study suggests that the central antinociceptive action induced by antimigraine drugs is independent from Gi proteins.

Keywords Indomethacin Prochlorperazine - Caffeine · Sumatriptan $\cdot$ Migraine $\cdot$ Gi proteins

\section{Introduction}

It is worldwide recognized that specific drugs are the most effective in the acute treatment of migraine, in particular in patients with moderate or severe pain [1]. The fixed combination of indomethacin, prochlorperazine and caffeine (hereinafter Indoprocaf) is a drug of well-established use in Italy, with a recognized efficacy and a good level of safety both in the acute treatment of migraine $[2,3]$ and tensiontype headache [4].

In contrast to other non-steroidal anti-inflammatory drugs (NSAIDs), indomethacin has an indole nucleus which is similar to serotonin and to the $5 \mathrm{HT}_{1 \mathrm{~B} / 1 \mathrm{D}}$ agonists known as triptans. The efficacy of indomethacin in the treatment of migraine and other primary headaches might be due to its central analgesic activity [5], its ability to abolish peripheral and central hyperalgesia [6-8], its vasoconstrictive effect on cerebral vessels [9-11] and its ability to inhibit neurogenic inflammation [12]. The mechanism of action of prochlorperazine in migraine could be attributed to its central cholinergic analgesic effect [13] and to its ability to abolish hyperalgesia [6,7]. Caffeine is used as an effective analgesic adjuvant in various analgesic combinations. It is a non-selective antagonist of adenosine $A_{1}$ and $A_{2}$ receptors [14]. Its positive effects in the symptomatic treatment of headache are attributed to an 
increased analgesic action of other drugs [14], a central cholinergic analgesic effect [15], its ability to abolish hyperalgesia [6] and a vasoconstrictive activity [16].

Indoprocaf, administered i.p. at sub-analgesic doses in mice, showed to be able to reverse hyperalgesia induced by morphine withdrawal and to be superior to each single active ingredient in abolishing hyperalgesia induced by a $0.3 \%$ solution of acetic acid i.p. injected [6]. Moreover, Indoprocaf, but not sumatriptan, administered i.p. at subanalgesic doses in mice, was able to abolish peripheral and central sensitization [7].

Nearly all inhibitory neurotransmitters which are able to enhance the pain threshold use $\mathrm{Gi}$ proteins as signal transduction system. Gi proteins reduce neurones excitability through the inhibition of adenylate cyclase activity and modulation of several $\mathrm{K}^{+}$and $\mathrm{Ca}^{2+}$ channels [17]. A hypofunctionality of Gi proteins has been found in lymphocytes of patients with migraine and cluster headache [17]. The intracerebroventricular administration of pertussis toxin (PTX) selectively inhibits Gi proteins and blocks the antinociceptive action of common analgesic drugs such as opioids (morphine), histamine $\mathrm{H}_{1}$ receptor antagonists (diphenhydramine), $\mathrm{GABA}_{\mathrm{B}}$ agonists (baclofen), tricyclic antidepressants (clomipramine), but not of cholinesterase inhibitors (physostigmine), in the mouse hot plate test $[18,19]$.

The aim of this study was to investigate if Indoprocaf was able to exert its central antinociceptive action when Gi proteins activity is inactivated by PTX, compared to its single active ingredients and to sumatriptan, in the mice model of abdominal constriction test induced by a $0.6 \%$ solution of acetic acid i.p. injected.

\section{Methods}

Animals

Male albino mice (20-25 g) from Morini breeding farm (San Polo d'Enza-Italy) were used. All experiments were carried out according to the guidelines of the European Community Council Directive dated November 24, 1986 (86/609/EEC) for experimental animal care. All efforts were made to minimize suffering and to reduce the number of animals used.

Pertussis toxin administration

Mice were randomly assigned to the intracerebroventricular administration of PTX $(0.25 \mu \mathrm{g}$ per mouse $)$ or to a saline solution 9 days before the abdominal constriction test. Intracerebroventricular administration was performed under ether anaesthesia using isotonic saline as a solvent, according to the method of Haley and McCormick [20]. During anaesthesia, mice were grasped firmly by the loose skin behind the head. A 0.4-mm external diameter hypodermic needle attached to a $10-\mu 1$ syringe was inserted perpendicularly through the skull and no more than $2 \mathrm{~mm}$ into the brain of the mouse, where $5 \mu \mathrm{l}$ were then administered. The injection site was $1 \mathrm{~mm}$ to the right or left from the midpoint on a line drawn through to the anterior base of the ears. Injections were performed into the right or left ventricle randomly. To ascertain that the drugs were administered exactly into the cerebral ventricle, some mice were injected with $5 \mu \mathrm{l}$ of Indian ink diluted 1:10 and their brains were examined macroscopically after sectioning.

\section{Drugs}

The following drugs were used: indomethacin (non-steroidal anti-inflammatory drug-Sigma, Milan, Italy), prochlorperazine ( $\mathrm{D}_{2}$-antagonist-Sigma, Milan, Italy), caffeine (adenosine antagonist-Sigma, Milan, Italy), sumatriptan $\left(5-\mathrm{HT}_{1 \mathrm{~B} / 1 \mathrm{D}}\right.$ agonist-GlaxoSmithKline) and PTX (RBI).

The doses of the tested drugs were chosen on the basis of their analgesic efficacy in the $0.6 \%$ solution of acetic acid-induced abdominal constriction test: indomethacin $(1 \mathrm{mg} / \mathrm{kg}$, s.c.), prochlorperazine (1 mg/kg, s.c.) [13], caffeine (3 mg/kg, s.c.) [15] and sumatriptan $(20 \mathrm{mg} / \mathrm{kg}$, s.c.) [21] (Table 1). A fixed combination of indomethacin $(1 \mathrm{mg} / \mathrm{kg})$, prochlorperazine $(1 \mathrm{mg} / \mathrm{kg})$ and caffeine (3 $\mathrm{mg} / \mathrm{kg}$ ) was s.c. administered.

According to their pharmacokinetics, in order to reach the analgesic peak in correspondence of the abdominal constriction test, the tested drugs were s.c. administered

Table 1 Analgesic and antihyperalgesic doses of indomethacin, prochlorperazine and caffeine as Indoprocaf, and sumatriptan

\begin{tabular}{lllll}
\hline & $\begin{array}{l}\text { Analgesic doses from } \\
\text { the literature }(\mathrm{mg} / \mathrm{kg})\end{array}$ & $\begin{array}{l}\text { Analgesic doses in the PTX } \\
\text { experiment }(\mathrm{mg} / \mathrm{kg})\end{array}$ & $\begin{array}{l}\text { Antihyperalgesic } \\
\text { doses }(\mathrm{mg} / \mathrm{kg})\end{array}$ & $\begin{array}{l}\text { Oral antimigraine doses } \\
\text { in the clinical practice }(\mathrm{mg})\end{array}$ \\
\hline Indomethacin & $1[23]$ & 1 & $0.1[7]$ & $25[3]$ \\
Prochlorperazine & $1-2[13]$ & 1 & $0.1[7]$ & $2[3]$ \\
Caffeine & $1-5[15]$ & 3 & $0.3[7]$ & $75[3]$ \\
Sumatriptan & $10-30[21]$ & 20 & $1[24]$ & $50[3]$ \\
\hline
\end{tabular}


$30 \mathrm{~min}$ (prochlorperazine and sumatriptan) or $15 \mathrm{~min}$ (indomethacin, caffeine and Indoprocaf) before the acetic acid injection. A control group was treated with a saline solution.

\section{Abdominal constriction test}

Mice were intraperitoneally injected with a $0.6 \%$ solution of acetic acid $(10 \mathrm{ml} / \mathrm{kg})$ according to the method of Koster [22]. The analgesic effect was evaluated through the count of abdominal constrictions. The number of stretching movements was counted for $10 \mathrm{~min}$, starting $5 \mathrm{~min}$ after the acetic acid injection. Ten animals per group were used.

\section{Statistics}

Results from abdominal constriction tests are given as the mean \pm SEM. Analysis of variance (ANOVA), followed by Fisher's PLSD procedure for post-hoc comparison, was used to verify the significance between two means. $P$-values of less than 0.05 were considered significant. Data were analyzed with the StatView program (version 4.01) for the Macintosh computer.

\section{Results}

In the abdominal constriction test, indomethacin $(1 \mathrm{mg} / \mathrm{kg}$, s.c.), prochlorperazine (1 $\mathrm{mg} / \mathrm{kg}$, s.c.) and caffeine $(3 \mathrm{mg} /$ $\mathrm{kg}$, s.c.) induced a statistically significant central antinociceptive effect also when the Gi proteins were inactivated (Table 2), due to the administration of PTX, in comparison with the control group.

Also sumatriptan $(20 \mathrm{mg} / \mathrm{kg}$, s.c.) was able to reduce significantly the abdominal constrictions when the $\mathrm{Gi}$ proteins were inactivated by the PTX (Table 2; Fig. 1).
The combination of indomethacin $(1 \mathrm{mg} / \mathrm{kg})$, prochlorperazine $(1 \mathrm{mg} / \mathrm{kg})$ and caffeine $(3 \mathrm{mg} / \mathrm{kg})$, s.c. administered, induced a statistically significant reduction of abdominal constrictions even when the Gi proteins were inactivated by the PTX (Table 2; Fig. 2). The reduction induced by the combination was statistically superior to that of each of its single active ingredients and to that of sumatriptan (Table 2; Fig. 3). Moreover, also when used as analgesic in the control group (saline + drug), the combination of indomethacin, prochlorperazine and caffeine induced a superior antinociceptive effect than that obtained with the same analgesic dose of each single active ingredient and than sumatriptan (Table 2).

\section{Discussion}

The aim of this study was to investigate if Indoprocaf was able to exert its central antinociceptive action when Gi proteins activity is abolished by PTX, compared to its single active ingredients and to sumatriptan, in the mice model of abdominal constriction test induced by an i.p. injection of $0.6 \%$ solution of acetic acid. This study showed that Indoprocaf and sumatriptan at analgesic doses exert their central antinociceptive action independently from the Gi proteins. In addition, the antinociceptive efficacy of Indoprocaf in this study was statistically superior to that of sumatriptan.

This study also showed that the single active ingredients of Indoprocaf, indomethacin, prochlorperazine and caffeine, were able to exert their central antinociceptive action independently from the Gi proteins.

Considering that prochlorperazine and caffeine induce a central cholinergic analgesia $[13,15]$ and that the central cholinergic system was proven to have a role in the antinociception induced by sumatriptan in rodents [21], these

Table 2 Effect of indomethacin, prochlorperazine, caffeine, Indoprocaf and sumatriptan in mouse abdominal constriction test, with and without pertussis toxin $(\mathrm{PTX})($ mean \pm SEM)

\begin{tabular}{|c|c|c|c|c|}
\hline & \multicolumn{4}{|c|}{ No. of abdominal constrictions } \\
\hline & Saline/saline & PTX/saline & Saline/drug & PTX/drug \\
\hline Indomethacin $(1 \mathrm{mg} / \mathrm{kg}$, s.c. $)$ & $31.4 \pm 4.2$ & $33.5 \pm 2.3$ & $16.1 \pm 3.3^{*}$ & $13.8 \pm 3.7^{\circ}$ \\
\hline Prochlorperazine (1 mg/kg, s.c.) & $27.1 \pm 3.3$ & $31.6 \pm 2.4$ & $15.1 \pm 2.6^{*}$ & $16.6 \pm 3.0^{\circ}$ \\
\hline Caffeine (3 mg/kg, s.c.) & $30.1 \pm 1.3$ & $31.5 \pm 4.1$ & $14.8 \pm 3.3^{*}$ & $17.5 \pm 2.9^{\circ}$ \\
\hline Sumatriptan (20 mg/kg, s.c.) & $28.6 \pm 3.7$ & $29.8 \pm 3.1$ & $13.2 \pm 2.9^{*}$ & $14.4 \pm 2.7^{\circ}$ \\
\hline Indoprocaf (1/1/3 mg/kg, s.c.) & $28.3 \pm 1.6$ & $27.8 \pm 2.0$ & $3.9 \pm 1.1 * \S$ & $5.5 \pm 1.7^{\circ \wedge}$ \\
\hline
\end{tabular}

* $P<0.01$ vs. the corresponding saline/saline

${ }^{\circ} P<0.01$ vs. the corresponding PTX/saline

$\S P<0.01$ vs. Saline/Indomethacin or saline/prochlorperazine or saline/caffeine or saline/sumatriptan

$\wedge P<0.01$ vs. PTX/indomethacin or PTX/prochlorperazine or PTX/caffeine or PTX/sumatriptan

ANOVA 
Fig. 1 Effect of sumatriptan $(20 \mathrm{mg} / \mathrm{kg}$, s.c.) in mouse abdominal constriction test, with and without pertussis toxin (PTX) (mean \pm SEM); $* P<0.01$ vs. saline only treated mice, ${ }^{\circ} P<0.01$ vs. $\mathrm{PTX} /$ saline treated mice

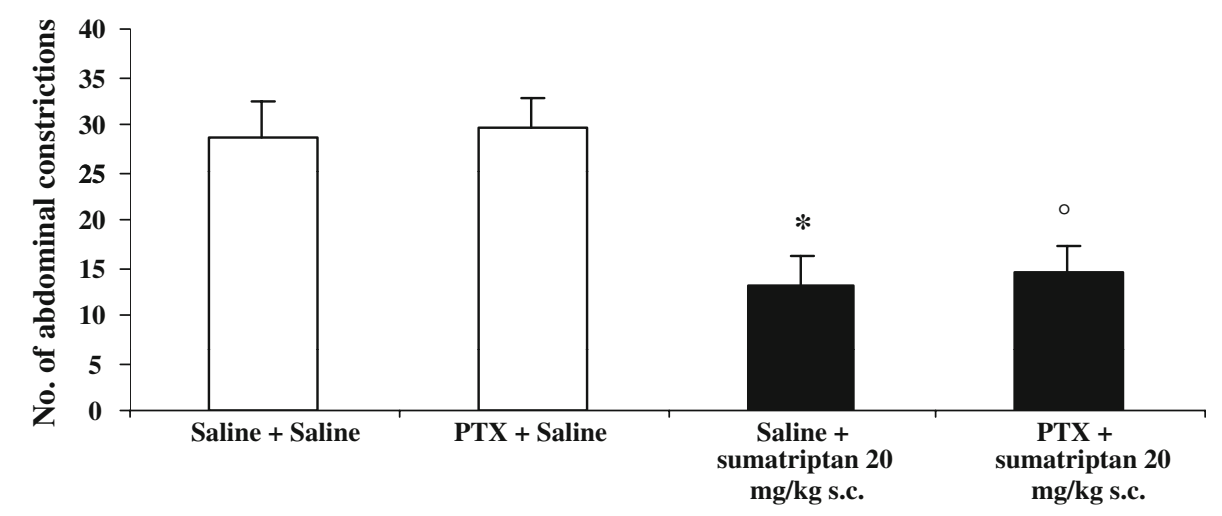

Fig. 2 Effect of Indoprocaf (indomethacin $1 \mathrm{mg} / \mathrm{kg}$, prochlorperazine $1 \mathrm{mg} / \mathrm{kg}$, caffeine $3 \mathrm{mg} / \mathrm{kg}$, s.c.) in mouse abdominal constriction test, with and without pertussis toxin (PTX) (mean \pm SEM); $* P<0.01$ vs. saline only treated mice, ${ }^{\circ} P<0.01$ vs. $\mathrm{PTX} /$ saline treated mice
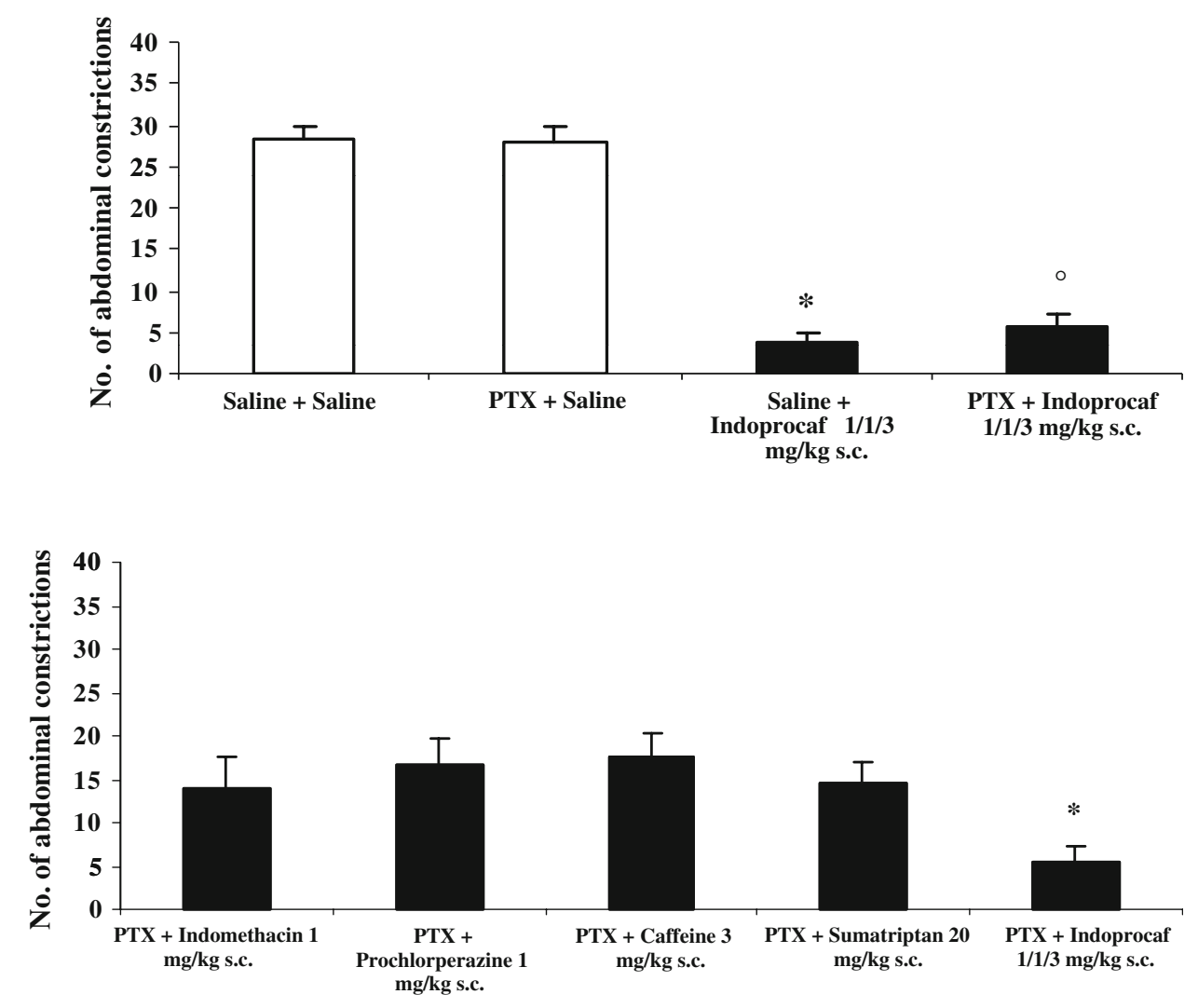

Fig. 3 Effect of indomethacin, prochlorperazine, caffeine, sumatriptan and Indoprocaf in mouse abdominal constriction test with pertussis toxin (PTX) (mean \pm SEM); $* P<0.01$ vs. indomethacin or prochlorperazine or caffeine or sumatriptan treated mice results are consistent with previous data showing that PTX had no effect on cholinergic drugs-induced analgesia [19]. To our knowledge, no other NSAID besides indomethacin has been tested in in vivo models of PTX-induced Gi proteins inactivation.

Moreover, this study showed that Indoprocaf at analgesic doses was able to abolish almost completely the abdominal constrictions, with a statistically superior efficacy compared to the single active ingredients, showing an important synergic effect of Indoprocaf. This synergic effect was evident not only when Gi proteins activity was abolished by PTX, but also under control condition, when Gi proteins were active. A synergic action of Indoprocaf at sub-analgesic doses, compared to its single active ingredients, was also proven in mice in the hyperalgesia model induced by the intraperitoneal injection of a $0.3 \%$ solution of acetic acid [6].

The dosages used for Indoprocaf in this experimental model are in the range of effective analgesic doses $[13,15,23]$ and are 10 times higher than those shown to be able to revert hyperalgesia $[6,7]$. The dose of sumatriptan used in this experimental model is in the range of effective analgesic doses [21] and is 20 times higher than that shown to revert hyperalgesia [24] (Table 1). From a clinical point of view, the therapeutic doses (orally administered) of indomethacin $(25 \mathrm{mg})$, prochlorperazine 
$(2 \mathrm{mg})$ and caffeine $(75 \mathrm{mg})$ contained in Indoprocaf as antimigraine drug are much lower than the range of doses of indomethacin (50-200 $\mathrm{mg}$ daily) when used to treat rheumatoid arthritis or pain of various aetiologies, of prochlorperazine (15-50 mg daily) when used as antiemetic and of anhydrous caffeine (100-200 mg) when used in analgesic preparations (Table 1). These dosages are consistent with the concept that migraine is a particular pain characterized by neuronal hyperexcitability and that migraine should be treated with specific drugs at dosages that could be sub-analgesic, but are antihyperalgesic [7]. Moreover, this study shows first that Indoprocaf is superior to its single active ingredients also at analgesic doses, supporting that, when used in the clinical practice, the doses of active ingredients in Indoprocaf could be lower than those of the single active ingredients when administered independently.

The central antinociceptive action exerted by Indoprocaf and sumatriptan independently from Gi proteins might be clinically important considering that it has been shown that in migraine patients there is a hypofunctionality of $\mathrm{Gi}$ proteins [17].

A hypofunctionality of $\mathrm{Gi}$ protein system has been reported also in patients suffering from fibromyalgia [25], and a high incidence of fibromyalgia was found among female migraine patients [26]. Many chronic pain syndromes, as fibromyalgia and chronic tension-type headache, show evidence of central nervous system hyperexcitability related to central sensitization [27, 28].

The efficacy of Indoprocaf both independently from the Gi protein functionality and in abolishing the central sensitization induced by N-methyl-D-aspartate (NMDA) in the experimental animal model [7] could imply a potential therapeutic value not only in migraine and tension-type headache but also in fibromyalgia, three conditions sharing some common features as an hyperalgesic state showing as increased pain sensitivity [29, 30].

\section{Conclusion}

This study suggests that the central antinociceptive action exerted by Indoprocaf and sumatriptan is independent from $\mathrm{Gi}$ proteins. The superiority of Indoprocaf compared to sumatriptan in this in vivo model supports the recent clinical evidence that Indoprocaf most likely has similar therapeutic efficacy to sumatriptan $[31,32]$, recognizing therefore the role of Indoprocaf in the acute treatment of migraine.

Acknowledgements This study was supported by an educational grant from Solvay Pharma S.p.A.
Conflict of interest Irene Grazioli and Carla Uslenghi are employees of Solvay Pharma S.p.A.

Open Access This article is distributed under the terms of the Creative Commons Attribution Noncommercial License which permits any noncommercial use, distribution, and reproduction in any medium, provided the original author(s) and source are credited.

\section{References}

1. Silberstein SD (2000) Practice parameter: evidence-based guidelines for migraine headache (an evidence-based review). Neurology 55:754-762

2. Di Monda V, Nicolodi M, Aloisio A, Del Bianco P, Fonzari M, Grazioli I, Uslenghi C, Vecchiet L, Sicuteri F (2003) Efficacy of a fixed combination of indomethacin, prochlorperazine, and caffeine versus sumatriptan in the acute treatment of multiple migraine attacks: a multicenter, randomized, crossover trial. Headache 43:835-844

3. Sandrini G, Cerbo R, Del Bene E, Ferrari A, Genco S, Grazioli I, Martelletti P, Nappi G, Pinessi L, Sarchielli P, Tamburro P, Uslenghi C, Zanchin G (2007) Efficacy of dosing and re-dosing of two oral fixed combinations of indomethacin, prochlorperazine and caffeine compared with oral sumatriptan in the acute treatment of multiple migraine attacks: a double-blind, doubledummy, randomised, parallel group, multicentre study. Int J Clin Pract 61(8):1256-1269

4. Cerbo R, Centonze V, Grazioli I, Tavolato B, Trenti T, Uslenghi C, Sternieri E (2005) Efficacy of a fixed combination of indomethacin, prochlorperazine, and caffeine in the treatment of episodic tension-type headache: a double-blind, randomized, nimesulide-controlled, parallel group, multicentre trial. Eur J Neurol 12(10):759-767

5. Hu XH, Tang H, Li Q, Huang X (1994) Central mechanism of indomethacin analgesia. Eur J Pharmacol 263:53-57

6. Galeotti N, Ghelardini C, Grazioli I, Uslenghi C (2002) Indomethacin, caffeine and prochlorperazine alone and combined revert hyperalgesia in "in vivo" models of migraine. Pharmacol Res 46(3):245-250

7. Ghelardini C, Galeotti N, Grazioli I, Uslenghi C (2004) Indomethacin, alone and combined with prochlorperazine and caffeine, but not sumatriptan, abolishes peripheral and central sensitization in in vivo models of migraine. J Pain 5(8):413-419

8. Jakubowski M, Levy D, Goor-Aryeh I, Collins B, Baywa Z, Burstein R (2005) Terminating migraine with allodynia and ongoing central sensitization using parenteral administration of COX1/COX2 inhibitors. Headache 45:850-861

9. Rasmussen M (2005) Treatment of elevated intracranial pressure with indomethacin: friend or foe? Acta Anaesthesiol Scand 49:342-350

10. Matharu S, Cohen SA, Frackowiak RS, Goadsby PJ (2006) Posterior hypothalamic activation in paroxysmal hemicrania. Ann Neurol 59:535-545

11. Castellano AE, Micieli G, Bellantonio P, Buzzi MG, Marcheselli S, Pompeo F, Rossi F, Nappi G (1998) Indomethacin increases the effect of isosorbide dinitrate on cerebral hemodynamic in migraine patients: pathogenetic and therapeutic implications. Cephalalgia 18:622-630

12. Buzzi MG, Sakas DE, Moskowitz MA (1989) Indomethacin and acetylsalicylic acid block neurogenic plasma protein extravasation in rat dura mater. Eur J Pharmacol 165:252-258 
13. Ghelardini C, Galeotti N, Uslenghi C, Grazioli I, Bartolini A (2004) Prochlorperazine induces central antinociception mediated by the muscarinic system. Pharmacol Res 50(3):351-358

14. Zhang WY (2001) A benefit-risk assessment of caffeine as an analgesic adjuvant. Drug Saf 24(15):1127-1142

15. Ghelardini C, Galeotti N, Bartolini A (1997) Caffeine induces central cholinergic analgesia. Naunyn-Schmiedebergs Arch Pharmacol 356:590-595

16. Mathew RJ, Wilson WH (1985) Caffeine consumption, withdrawal and cerebral blood flow. Headache 25:305-309

17. Galeotti N, Ghelardini C, Zoppi M, Del Bene E, Raimondi L, Beneforti E, Bartolini A (2001) Hypofunctionality of Gi proteins as aetiopathogenic mechanism for migraine and cluster headache. Cephalalgia 21(1):38-45

18. Parenti M, Tirone F, Giagnoni G, Pecora N, Parolaro D (1986) Pertussis toxin inhibits the antinociceptive action of morphine in the rat. Eur J Pharmacol 124:357-359

19. Galeotti N, Ghelardini C, Bartolini A (1996) Effect of pertussis toxin on morphine, diphenhydramine, baclofen, clomipramine and physostigmine antinociception. Eur J Pharmacol 308:125133

20. Haley TG, McCormick GL (1957) Pharmacological effects produced by intracerebral injections of drugs in the conscious mouse. Br J Pharmacol Chemother 12:12-15

21. Ghelardini C, Galeotti N, Figini M, Imperato A, Nicolodi M, Sicuteri F, Gessa GL, Bartolini A (1996) The central cholinergic system has a role in the antinocicetion induced in rodents and guinea pigs by the antimigraine drug sumatriptan. J Pharmacol Exp Ther 279:884-890

22. Koster R, Anderson M, De Beer EJ (1959) Acetic acid for analgesic screening. Fed Proc 18:412-413

23. DeLeo JA, Colburn RW, Coombs DW, Ellis MA (1989) The differentiation of NSAIDs and prostaglandin action using a mechanical visceral pain model in the rat. Pharmacol Biochem Behav 33(1):253-255

24. Ghelardini C, Galeotti N, Donaldson S, Nicolodi M, Sicuteri F, Bartolini A (1996) Prevention by sumatriptan of hyperalgesia induced by morphine withdrawal. Fundam Clin Pharmacol 10(2): 192

25. Galeotti N, Ghelardini C, Zoppi M, Del Bene E, Raimondi L, Beneforti E, Alessandro A (2001) A reduced functionality of Gi proteins as a possible cause of fibromyalgia. J Rheumatol 28(10):2298-2304

26. Ifergane G, Buskila D, Simiseshvely N, Zeev K, Cohen H (2006) Prevalence of fibromyalgia syndrome in migraine patients. Cephalalgia 26:451-456

27. Staud R, Price DD, Robinson ME, Mauderli AP, Vierck CJ (2004) Maintenance of windup of second pain requires less frequent stimulation in fibromyalgia patients compared to normal controls. Pain 110:689-696

28. Schoenen J (2004) Tension-type headache and fibromyalgia: what's common, what's different? Neurol Sci 25:S157-S159

29. Nicolodi M, Sicuteri F (1998) Fibromyalgia and headache. Failure of serotonergic analgesia and N-methyl-D-aspartatemediated neuronal plasticity: their common clues. Cephalalgia 18(Suppl 21):41-44

30. Ashina S, Bendtsen L, Ashina M, Magerl W, Jensen R (2006) Generalized hyperalgesia in patients with chronic tension-type headache. Cephalalgia 26:940-948

31. Mett A, Tfelt-Hansen P (2008) Acute migraine therapy: recent evidence from randomized comparative trials. Curr Opin Neurol 21:331-337

32. Tfelt-Hansen P (2008) Triptans vs other drugs for acute migraine. Are there differences in efficacy? A comment. Headache 48:601605 